\title{
Students' Home Visit Experiences within the Scope of Public Health Nursing Course: A Qualitative Study
}

\author{
Nilgün Kuru Alıcı®, Oya Nuran Emiroğlu®
}

Hacettepe University, Faculty of Nursing, Ankara, Turkey

Nilgün Kuru Alıcı, Assis. Prof. Oya Nuran Emiroğlu, Prof.

\section{Correspondence:}

Assis. Prof. Nilgün Kuru Alıcı Hacettepe University, Faculty of Nursing, Ankara, Turkey

Phone: +90312305 1580/149

E-mail: nilgun.kuru@hacettepe.edu.tr

Received : July 19,2019

Revised : November 10, 2019

Accepted : November 19, 2019

\section{ABSTRACT}

Purpose: The purpose of this study was to explore the experiences of nursing students' home visits within the context of the public health nursing course.

Patients and Methods: This was a qualitative descriptive study based on the student's reflective essay. The study was completed with 110 senior students in the nursing faculty of a public university in Turkey. Students explained self-perceptions (abilities, skills and feelings) before and after the home visits process of public health nursing field practice at the end of the semester.

Results: The experiences of students before the field practice were grouped under the themes of "security", "concerns about the family process" and "feeling insufficient". The themes "job satisfaction", "being useful to the families", and "contribution to personal development" emerged from the data collected after the field practice was completed.

Conclusions: This brief educational intervention allows students to feel useful to the families and the practice contributed to their personal development. It can improve the readiness of students for home visits with undergraduate programs because nursing students meet the "real world".

Keywords: Home visit, public health nursing, nursing education, student's experiences

HALK SAĞLIĞI HEMŞİRELIĞi DERSi KAPSAMINDA YAPILAN EV ZiYARETLERINE İLişKIN ÖĞRENCi DENEYIMLERI: NITEL ARAŞTIRMA

ÖZET

Amaç: Bu çalışmanın amacı hemşirelik öğrencilerinin halk sağlığı hemşireliği dersi kapsamında yaptıkları ev ziyaretlerine ilişkin deneyimlerinin tanımlanmasıdır.

Hastalar ve Yöntem: Bu çalışma öğrenci görüşlerini yansıtan nitel bir araştırmadır. Türkiye'deki bir devlet üniversitesinin son sınıf 110 öğrencisi ile yürütülmüştür. Öğrencilerin halk sağlığı hemşireliği saha uygulaması öncesi ve sonrası deneyimlerini açıklamaktadır.

Bulgular: Öğrencilerin saha uygulama öncesi deneyimleri "güvenlik", "aile sürecine ilişkin endişe" ve "kendini yetersiz hissetme" ana temalarından oluşmuştur. Öğrencilerin saha uygulama sonrası deneyimlerinden elde edilen veriler doğrultusunda ise "iş doyumu", "ailelere faydalı olma" ve " kişisel gelişime katkı" başlıklarının öne çıktığı görülmüştür.

Sonuç: Bu kısa eğitim uygulaması, öğrencilerin ailelere faydalı olmalarına ve kendi kişisel gelişimlerine katkıda bulunmalarına yardımc olmuştur. Hemşirelik öğrencileri "gerçek dünya" ile tanıştıkları için öğrencilerin lisans programları ile ev ziyaretlerine hazır olmalarını geliştirebilir.

Anahtar sözcükler: Ev ziyaretleri, halk sağlığı hemşireliği, hemşirelik eğitimi, öğrenci deneyimleri 
ncreasing the quality of nursing education is an important way of strengthening health systems. Nursing education is mainly addressed by accredited institutions that meet the vocational training standards, include quality education processes, and offer specialized and advanced vocational training programs (1). In Turkey, basic nursing education is maintained in accordance with universal standards at the undergraduate level at universities. Nursing undergraduate programs aimed at helping students acquire clinical skills as well as equipping them with the necessary community-oriented care skills. In the final semester of the undergraduate program, with public health nursing course, it is aimed to equip nursing students with these skills (2). Public health nursing is a period of nursing care delivery aimed at improving the health of the community (3). In this period, public health nurse plays an active role in the development, protection, treatment and rehabilitation of the health of individuals and families living in the community (4). Graduates of nursing departments are expected to have received basic level of public health nursing education (1). The public health nursing undergraduate course was offered to reach this aim and it is composed of theoretical and practical parts. In the theoretical part of the course, students learn the practices of public health nursing by considering individuals of all ages, families and the community in all the spheres they live and work, within a process from the development of health to the level of rehabilitation. In the practical part of the course, it is aimed to develop the knowledge and skills of students through the "home visit" experience in which students get to know the community and family in practice. During home visits, students learn about the people, family and society in the environment they live, identify their health problems, determine the priorities in a realistic way, look for solutions with the participation of the person or the family, and put those solutions into practice.

The studies conducted in Turkey revealed that students faced a great deal of resistance during the home visits they provided within the context of the public health nursing course. They stated that the practice was beneficial for neither the society nor themselves, and families were not willing to accept home visits by student nurses as they were not available $(5,6)$. There is a limited study that analysis written reflection paper was applied to the students' home visit experiences and also this is the first study conducted with this methodology in Turkey. This study's objective was to evaluate changes in students', skills, abilities and self-perceptions related to home visits before and after home visit completion. In this respect, it is believed that conducting the present study will be beneficial for public health nursing students and educators for the fact that we have limited literature.

\section{Methods}

\section{Design \& Procedure}

This was a qualitative descriptive phenomenological study based on a student's reflective essay. (7). Eyler (2002) stressed the importance of reflecting before (what she called "preflection??"), during, and after a service-learning experience (8). Reflecting before an experience allows a student to question his or her assumptions, to make educated guesses about the experience, and to set personal goals for him or herself (9).

The purpose statements of this study were to:

1) Explore self-perceptions (abilities, skills and feelings) before planning the process of public health nursing field practice

2) Assess students' changing evaluations after the completion process of public health nursing field practice

\section{Participants \& data collection}

Participants were undergraduate senior students in the nursing faculty of a public university in Ankara capital of Turkey in the spring semester of 2016-2017 academic year. The research population was composed of 132 . The semi-structured written reflection paper was applied to the students who agreed to participate in the survey two weeks after the final exam was over. The study was completed with 110 students. Data were collected in Turkish then translated to English by the researchers.

Home visit process within the scope of the public health nursing course in this nursing faculty

Home visits were conducted in areas where the university received permission for the practice. During the 20162017 academic year, the students provided home visits in six districts of the capital city Ankara, which are Ayrancı, Bademlidere, Çubuk, Pursaklar, Şentepe and Etimesgut. Senior nursing students provided home visits for 10 weeks, 2 full days and 1 half-day per week. There were 22 nursing students and one faculty member for each region, who gave consultancy to the students during the process when necessary. Also, the faculty members provided at least two home visits together with the students to improve the home visits process. Nursing students found their targeted families for home visits from 
family health centers and schools. Each nursing student was held responsible for nursing care for 3 families and was obliged/asked/required to conduct at least 2 home visits per week. Nursing students followed a nursing process for the assessment of the community and families including nursing diagnosis, plan, intervention, and evaluation. Although the health needs of the families and communities living in each region are different from each other, the common needs were related to problems such as chronic diseases (hypertension, diabetes, COPD, etc.), use of medicines, pregnancy and baby monitoring, child development, adolescence, old age, depression, and nutrition. Students identified the priority health needs with the family and tried to find solutions together. They were expected to manage this process drawing on the roles and responsibilities of the public health nurses.

\section{Data analysis}

A content analysis of the students' written reflection papers was performed to determine the themes. Initially, all students' documents were read and re-read by authors, and then started the production of initial codes for data. Coding has been done manually. Authors used highlighters, colored pens or post-it notes to take notes on the text for their analysis. Two authors continued to analyze the findings independently and to collate the emerging categories. After they have coded all of their data, each author explained his or her category, and then all of the authors returned to the original data to review the text and agree on the category that represented the data most faithfully.

\section{Ethical considerations}

There are no ethical conflicts or conflicts of interests because this study conducted with scope of Public Health Nursing Course. Before the written reflection papers were applied, written permission was obtained from the head of the public health nursing department. The students were informed about the purpose of the study. Their written consent was obtained.

\section{Results}

The experiences of students before the field practice were grouped under the themes of "security", "concerns about the family process" and "feeling insufficient" (Figure 1).

\section{Security}

As far as students' concerns about security prior to field practice are concerned, S11 stated that security was the biggest problem for her and it was a very frightening experience. S18 said "I had fears. I was highly worried about being defenseless in a closed area as I did not know

\section{The experiences of students before the field practice}
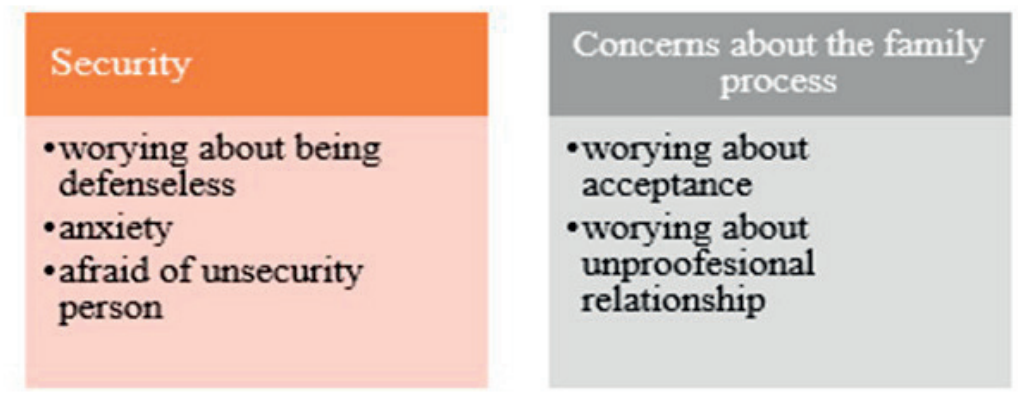

Feeling insufficent

-worying about unuseful

-worying about applying

nursing intervention

- not feeling sure about being useful or effective

\section{The experiences of students after the field practice was completed.}

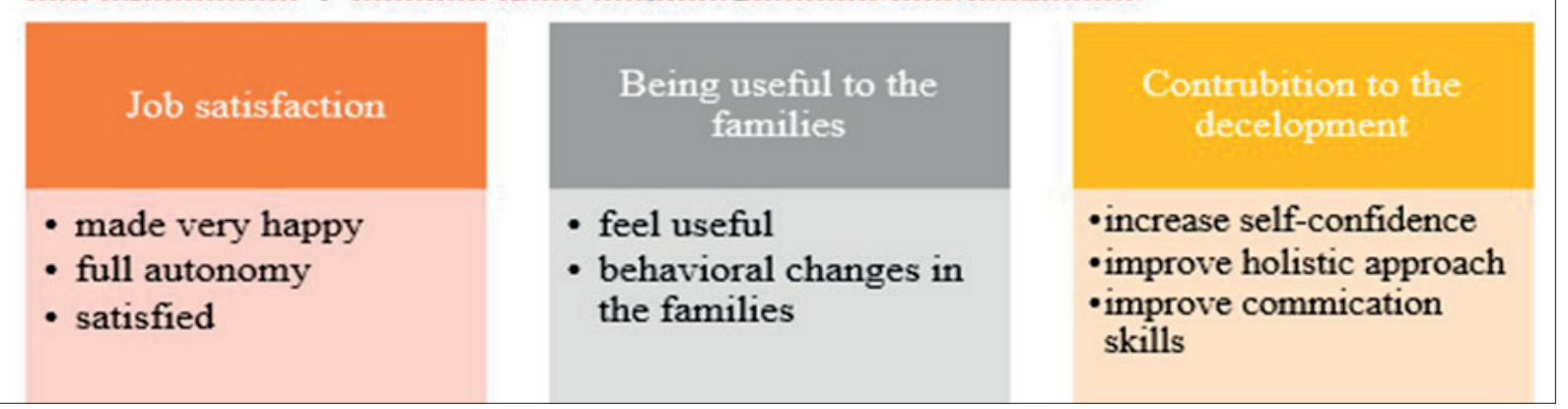

Figure 1. The experiences of students before and after the field practice were grouped under the themes 
the characters of the individuals in the house". Another student, S26, said, "I was always thinking whether I would experience a bad situation or what I would do if something bad happened during the visit". S33 said, "I did not think it was safe to look for a family by knocking on the door. I also thought if I should carry a pepper gas/spray with me. I was thinking what I could do if something bad happened to me during the visits". S77 mentioned the safety issue as well: "I had serious concerns about security because we were expected to provide home visits to families we did not know in the areas. We could have met every kind of person and situation like thieves, perverts, harassment, etc. I did not want the practice to start".

\section{Concerns about the family process}

Students made the following statements regarding the theme concerns about the family process:

S14 stated that she was worried about how she would find a house/the address, whether people would accept her and whether she could express herself, and what would happen when she went into the house. S45 said, "I was worried because this practice was different from the other practices, and I did not know what to do and I was worried that I would not be able to help the people at home". Another student, S47, said, "I was worried about whether they would accept me and how I would manage the process". Furthermore, S79 stated that she was highly afraid and she thought she could not manage the process. She said she had prejudices, and thought that none of the families would accept her into their houses. On the other hand, S102 said, "I perceive the home environment as the private area of the family, so I was worried about the possibility of not establishing a professional relationship and families wanting to end the visit in the middle of the process". Another student, S108, said, "I was worried about not being able to ensure the continuity of home visits".

\section{Feeling insufficient}

As far as the theme feeling insufficient is concerned, students made the following statements:

S23 said "The first thing I was concerned about before the home visits was not security, but the feeling that I would not be useful enough for the people I visit. Until that time, there were people we depended on in the clinics like our instructors, the nurses, etc. I was very uneasy about taking the whole responsibility on my own during the visits". Furthermore, S30 stated that she had concerns about not being able to respond to the needs of the families. On the other hand,
S50 said, "I felt I might have had communication difficulties with the family and I was insufficient to educate the parents". While S71 told that he was concerned about how to respond to the health-related questions of the families, S83 said she was concerned about being insufficient about the practices and the care she would give to the family she visited. Moreover, while S91 said, "I was worried about applying nursing interventions in an unfamiliar environment", S97 said she did not feel sufficient to help the families; she thought she would be useless.

The themes "job satisfaction", "being useful to the families", and "contribution to personal development" emerged from the data that were collected after the field practice was completed (Figure 1).

\section{Job satisfaction}

Students' statements regarding "job satisfaction" after the field practice are as follows:

S1 stated that this practice was the most productive and that she felt highly competent and functional. S13 said, "I think that I was very useful to the families. The positive feedback I received made me very happy and increased the satisfaction I got from my job". Furthermore, S18 stated that gathering data in the best way possible, making the right diagnosis, preparing the best care plans for the families, and giving education and information about them caused her to feel the nursing profession in real sense. S26 also said that it was both satisfactory and valuable to see that the training she gave was put into practice. Another student, S36 believed that to have full autonomy and to perform the nursing profession outside of the clinic was a highly satisfying experience. Furthermore, S47 said, "I felt really satisfied when the families said they had put into practice what I told them to do in my previous visit".

\section{Being useful to the families}

The following statements of the students exemplify the theme of "being useful to the families":

S7 said "I saw that even a little piece of information caused significant changes in the lives of the families, and they had an insatiable desire for knowledge. Everything was beautiful after establishing a trust relationship. I wanted to give more training and information as I saw that I was useful and they changed". Similarly, S15 said, "I was very happy to see that I have been useful to the families since I met them and that they have been demanding (willing to learn more) about their health". Another student, S28, told that she led to 
some behavioral changes in the families thanks to the training she provided. S39 also touched upon the theme saying that she realized with home visits she could prevent many health problems that may emerge in society early and she could solve the existing problems in an effective way. Furthermore, $\$ 94$ stated that he realized how important health education given to people at different socio-cultural backgrounds. 97 said, "I saw that I could be useful to the families by informing them about an issue that seemed unimportant".

\section{Contribution to personal development}

The students who stated that field practice makes a "contribution to personal development" expressed their opinions as follows:

S12 said, "I improved my communication skills; it was a productive internship in which my self-confidence improved as I felt useful to the community and the families". S23 stated that she felt ready for the profession as she saw that she applied her professional knowledge and skills on her own. She added that taking responsibility on her own increased her self-confidence and that her timidness disappeared after the field practice. Furthermore, S32 said that preparing training for the individual or group-specific needs improved her effectiveness and interpersonal communication skills and she understood the importance of mutual trust. Another student, S49, stated that he improved the holistic approach to the individual by observing the family at home and improving himself in terms of giving training. On the other hand, S58 said that the practice contributed to both her education and socialization. $\mathrm{S} 88$ remarked that the field practice gave the nursing students experience in how to approach people empathically and in giving training and counseling to individuals outside the hospital.

\section{Discussion}

The results of the present study which evaluated the experiences of the nursing students before and after the public health nursing field practice revealed that prior to the practice, the students thought that their safety might be in danger and that they might be insufficient in managing the family process. In similar studies, students stated that they were nervous and excited before the practice because they did not know what they would experience. They further stated that they were concerned because they thought that the level of their professional knowledge was not enough, that they would not be able to meet the needs of the families they visited, and that the home visits could pose a danger to their safety $(10,11)$. The experience of giving care to individuals at home for the first time may lead to anxiety and fear for students. The lack of the usual security measures that they encounter in institutions may have caused them to feel insecure. Students may also have felt worried thinking that they will have to provide home visits alone because they have never been alone in clinical practice. Maybe, student's behavioral responses can be tempered and enhanced by education, administrative support, and personal empowerment (12).

After the public health nursing field practice, the students stated that their home visits increased their job satisfaction; they felt they were beneficial to the families; and that this process contributed to their personal development. Other studies which evaluated students' experiences with home visits have shown that students provided training and consultancy to families; they have had the opportunity to improve their knowledge and teamwork skills and to observe the families to whom they provided care in the home environment and they now feel more independent $(6,13,14)$. As the students planned and conducted the home visits with the families during the public health field practice, they may have felt more independent by adopting the manager and planner roles. In addition, during home visits, the students assessed the health needs of the individuals themselves, made nursing care plans, and put them into practice immediately, which were all effective in meeting the health needs of individuals and families. The students had the opportunity to observe the results of the care they provided in every home visit. This may have increased their job satisfaction as the continuity of care was ensured. We believe that with the health training they have planned to create knowledge, attitude, and behavior change in the families, the students may have been beneficial to the families as well as contributing to their own development.

\section{Conclusion}

While the students were concerned about safety before the public health nursing field practice, they also stated that they felt incompetent about managing the family process and meeting the needs of the families. After the practice, the students stated that the public health nursing field practice led to an increase in their occupational satisfaction level. Moreover, they said they felt useful to the families and the practice contributed to their personal development. Home visits conducted within the practice part of the public health nursing course are a good 
opportunity for nursing students. To better understand the concept of public health nursing and the roles and responsibilities associated with it, it is necessary for all undergraduate nursing students to carry out home visits in public health nursing field practice. It can improve the readiness of students for home visits with undergraduate programs because nursing students meet the "real world".

\section{Limitation}

This study had two main limitations. First, participants were selected from only one university, which limits the

\section{References}

1. World Health Organization. A framework for community health nursing education. 2015. Retrieved from: http://www.searo.who.int/ entity/nursing_midwifery/documents/SEA-NUR-467/en/. Rerrieved Date: 21.05 .2017

2. Maurer F.A. Smith C. M. Community/public health nursing practice: Health for families and populations. Elsevier Health Sciences, 2013:290-300.

3. Oermann M. N. Annual Review of Nursing Education. United States of America: Springer Publishing Company, 2003.

4. Clement I. Management of Nursing Services and Education-E-Book. India: Elsevier Health Sciences, 2015.

5. Kahraman S. Erkek Öğrenci Hemşirelerin Halk Sağlığı Stajında Yaşadıkları Endişe ve Deneyimler: Şanlıurfa Örneği. Turk J Public Health 2013;11: 207-11.

6. Altay B, Özge Ö.Z. Hemşirelik Bölümü Son Sınıf Öğrencilerinin Halk Sağlığı Kapsamında Yaptıkları Ev Ziyaretlerinde Karşılaştıkları Güçlükler Ve Profesyonel Hemşirelik Rolleri. Samsun Sağlık Bilimleri Dergisi, 2016; 1:1-12.

7. Starks H, Brown Trinidad S. Choose your method: A comparison of phenomenology, discourse analysis, and grounded theory. Qualitative health research, 2007; 17:1372-80. generalizability of the findings. Second, nursing students felt useful to the families but we didn't have families' experiences about home visits.

\section{Conflicts of Interest: None}

Funding: This research did not receive grants from funding agencies in public, commercial, or not-for-profit sectors.

Acknowledgements: We thank all participants for their willingness to participate.

8. Eyler J. Reflection: Linking service and learning-linking students and communities. Journal of Social Issues, 2002;58:517-34. [CrossRef]

9. Perry S.L, Martin RA. Authentic reflection for experiential learning at international schools. The International Journal of Research on Service-Learning and Community Engagement. 2016: 4;53-68.

10. Leh S.K. Nursing students' preconceptions of the community health clinical experience: implications for nursing education. Journal of Nursing Education, 2011:50;620-7. [CrossRef]

11. Duah M.A. Baccalaureate Nursing Students' Perceptions of Community Health Nursing as a Career (Doctoral dissertation, Université d`Ottawa/University of Ottawa) 2015.

12. Kendra M.A, George V.D. Defining Risk in Home Visiting. Public Health Nursing. 2001;18: 128-37.

13. Babenko-Mould Y, Ferguson K, Atthill S. Neighbourhood as community: A qualitative descriptive study of nursing students' experiences of community health nursing. Nurse Educ. Pract, 2016:17; 223-8. [CrossRef]

14. Ozkan O, Ozdemir, S. Outcomes of planned home visits of intern public health nurses: An example from Turkey. Annals of Global Health, 2016;82: 885-96. 